\title{
THE USE OF TECHNOLOGY IN ENGLISH TEACHING \& LEARNING PROCESS
}

\author{
Rizky Andra Prayudi ${ }^{*}$ \\ Achmad Karunia Hakiki ${ }^{2}$ \\ Nanda Rezki Dermawan Putra ${ }^{3}$ \\ Tio Ocatviano Anzka ${ }^{4}$ \\ Muhammad Taufik Ihsan ${ }^{5}$ \\ 1,2,3,4,5 Departement of English Education, Faculty of Education and Teacher Training \\ State Islamic University of Sultan Syarif Kasim Riau, Indonesia

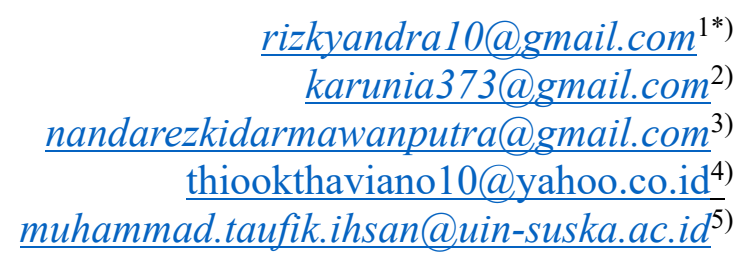

\begin{abstract}
Abstrak
This article is made to meet teacher teaching needs in using technology, especially in social media. For now, we are faced with Pandemic Covid-19 and also teachers continue to be demanded to be more careful in choosing the right technology when teaching online. This type of research is the method library research.This article is literature based in which the data and information were gathered from the book, internet postings, journal, etc. Technology includes the use of materials, tools, techniques and sources of power to make life easier. In education, Technology are really able to improve the teaching and leraning process.
\end{abstract}

Keywords: Technology, English teaching, Students, Application

Published by:

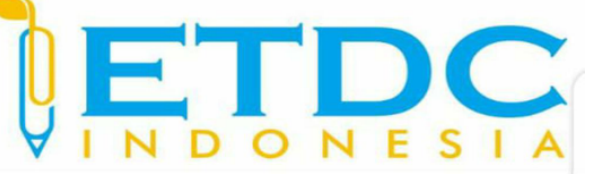

Copyright (C) 2021 The Author (s)

This article is licensed under CC BY 4.0 License

(cc) $\mathrm{BY}$ 


\section{THE USE OF TECHNOLOGY IN ENGLISH TEACHING \& LEARNING PROCESS}

\section{Introduction}

The use of modern technology in English teaching is widely understood as including the innovative application of methods, tools, materials, equipment, systems and strategies that are directly related to English language teaching and lead to the realization of expected goals. In addition, Ahmadi (2017) stated that one of the important elements for learning is the method that instructors use in Their classes to facilitate language learning process.

Therefore, although technology is now generally accepted as an important educational and auxiliary tool across a range of teaching and learning environments, English language teaching is especially true because it provides many potential opportunities to enhance the content and delivery of pedagogical methods that are often compared with traditional English. Language teaching related. According to Bull and Ma (2001), technology provides offers unlimited resources to language Learners. Harmer (2007) and Genç lter (2015) emphasized and teachers should encourage learners To find appropriate activities through using computer technology in order to be successful in Language learning. Clements and Sarama (2003) declare that the use of suitable technological Materials can be useful for learners.

Familiar with the concept of using modern technology is not limited to the use of modern appliances and equipment, but can also introduce innovative teaching systems and methods to promote faster and more comprehensive learning processes. Tomlison (2009) and Genç lter (2015) say that computer-based activities provide learners rapid information and appropriate materials. They continue that internet materials motivate learners to learn moreo

According to popular teaching theories, students can better acquire and hone their language knowledge and skills when using the learning potential of technology. According to Becker (2000), computers are Regarded as an important instructional instrument in language classes in which teachers have Convenient access, are sufficiently prepared, and have some freedom in the curriculum. Computer Technology is regarded by a lot of teachers to be a significant part of providing a high-quality Education.

According to Pourhosein Gilakjani (2013), the use of technologies has the great potential to change the existing language teaching methods. The use of technology in English teaching consolidates a comprehensive view of modern means systems and connections with other components, benefiting students by achieving desired results. 


\section{Methodology}

This article is literature based in which the data and information were gathered from the book, internet postings, journal etc. This article was written by following steps of collecting data and information, analyzed them, and presenting the result of analyzing, and making a summary of the result.

Based on the determination of time and spatial period, the application of historical methodology based on an analysis of the elements and reasons which gave rise to the basic research problem and the attendant challenges further assisted an evaluation of present and future developmental impacts.

In addition the collation, review and comparison of secondary data sourced from relevant records, reports and previous studies, were intrinsic to the design and scope of effective solutions. Problem Statement:

1. What is definition of technology?

2. What is the the use of technology in english teaching?

3. What are The Benefits of Technology in English Teaching?

4. What are the Technology in English teaching to Improve Students' Interest and Teaching Effect?

5. What is kind of ICT?

6. What are english learning apps?

\section{Discussion}

\section{a. Definition}

Technologies have already been defined by so many different researchers. According to ISSMAN (2012), it is the practical use of knowledge particularly in a specific area and is a way of doing a task especially using technical processes, methods, or knowledge. The usage of technology includes not only machines (computer hardware) and instruments, but also involves structured relations with other humans, machines, and the environment.

Teaching with technology is a wide topic that includes the role of media tools immplementation and integrated within Learning Management Systems (LMS) and those run more independently on the whole Internet. It also involves many different media types and also the functions.

In light of these multiple possibilities, the most consistent tip that arises in research pertaining to teaching with technology is that we choose particular technologies based on their compatibilities with the teaching and learning objectives associated with our courses and/or 
their individual units (Bates and Pool 2003).

\section{b. The Use of Technology in English Teaching}

The use of English has been increased in popularity and so has the need for qualified teachers to instruct students in the language. It is true that there are so many number of teachers who already use or implementing the technology. But, for the bad news, the majority of teachers are still teaching through the traditional manner. Actually, there is none of the traditional manners are considered as a bad or maybe potentially damaging the students. Because in reality, the fact is, till these days they are also proves as a still useful manners. However, there are so many more opportunities for students to gain more practice confidence and develop themselves, especially for ESL students, moreover to those who learn the language for more than just fun. For those type of ESL students, to keep pace with ELT and to have more confidence they have to stride into the world of multimedia technologies.

\section{c. Technology in English Teaching to Improve Students' Interest and Teaching Effect}

In these days, the traditional styled teaching methods \& environment are so much more unpopular while multimedia technology featuring audio, visual animation effects naturally and effectively makes us have more access to information. With such characteristics as abundantinformation and crossing time and space, multimedia technology offers a sense of reality and functions very well, which greatly processes and improves students' interest and motivation in study and their involvement in class activities.

\section{d. Benefits of Technology in English Teaching}

There are some studies have been done to finding out what are the advantages of technology usage in English language teaching and learning.

Hennessy (2005) stated the use of technology (ICT) acts very well in motivating the teachers and also the learners to work for the new ways. The researcher understood that as learners become more autonomous, teachers feel that they should urge and support their learners to act and think independently. The application of Computer Assisted Language Learning (CALL) changes learners' learning attitudes and enhances their self-confidence (Lee, 2001).

The use of technology has changed the methods from teacher-centered to learnercentered ones. Teachers should be the facilitators and should guide their learners' learning process and this change is very useful for learners to increase their learning (Riasati, Allahyar, $\&$ Tan, 2012). Gillespie (2006) said that the use of technology increases learners' cooperation in learning tasks. And of course it really helps them in gathering information and interacting with resources such as videos and others.

According to Rodinadze and Zarbazoia (2012), technology helps the students and 
teachers in studying the course materials owing to its fast access. Improvements in technology absolutely has the key role on preparing students to use what they learn in any subject matter to finding their place in the world labor-force. Technology facilitates the students' learning process and serves as a real educational tool that allows learning to occur.

When we have technologies are being integrated into our teaching and learning process, we will have already expecting that our students are becoming to be more interested in the subjects they are studying. Technology provides different opportunities to change the learning process becoming more fun, well different and enjoyable in terms of teaching same things in new ways. For instance, delivering teaching through gamification, taking students on virtual field trips and using other online learning resources. What is more, technology are also can be able to encourage a much way more active participation in the learning process which certainly can be hard to achieve through the traditional teaching $\&$ learning environment.

The learners who are involved and being interested in the things that tey are studying, are absolutely expected to have a more better knowledge retention. As mentioned before, technology can be able to help the teachers and their teching process to encourage an active participation in the classroom which also is a very important factor for increasing the knowledge retention. Some different kinds of technology can be used to be an experiment with, and also deciding what works best for the learners in terms of retaining their knowledge.

We can safe to say that there is no one of the students learns in the same way because of different learning styles and different abilities. The technology provides a very big chances for making the learning activities becoming way more effective for everyone with their own different needs. For example, students can learn at their own speed, review difficult concepts or skip ahead if they need to. What is more, technology can be able to provides more opportunities for some struggling or even disabled students. Access to the Internet gives students access to a broad range of so many different resources to conduct research in different ways, which in turn can increases the engagement.

And of course the students can be able to practice the collaboration skills by getting theirselves being involved in some different kind of online activities over the internet and technology. For instance, working on different projects by collaborating with others on forums or by sharing documents on their virtual learning environments. Technology can be able to encourage collaboration with students in the same classroom, same school and even with other classrooms around the world.

By using technology in the classroom, both the teachers and the students can develop so many skills during their teaching \& learning process. Students can be able to gain the skills they 
will need to be successful in the future. Modern learning is about collaborating with others, solving complex problems, critical thinking, developing different forms of communication and leadership skills, and improving motivation and productivity. What is more, technology can help develop many practical skills, including creating presentations, learning to differentiate reliable from unreliable sources on the Internet, maintaining proper online etiquette, and writing emails. These are very important skills that can be developed in the classroom.

Since there is a countless online resources, technology is really able to help the teaching and leraning process to be improved. Teachers can be able and may use different apps or trusted online resources to enhance the traditional ways of teaching and to keep students more engaged. Virtual lesson plans, grading software and online assessments can help teachers save a lot time. This valuable time can be used for working with students who are struggling. What is more, having virtual learning environments in schools enhances collaboration and knowledge sharing between teachers.

\section{e. Kind of ICT (Information and Communication Technology) \\ 1. Interactive multimedia}

Technology helps make it easy to combine several media including text, graphics, audio, video, and animation, to become computer program applications. Multimedia can usually be found on websites.

\section{Television}

Televisionis a system for converting visual images with sounds into electronic signals, transmitting them by radio or other means, and displaying them electronically on the screen.

\section{Computer}

Computer or Personal Computer (PC) is an electronic device which is capable of receiving data information and performing a sequence of logical operations in following with a predetermined but variable set of procedural instructions program to produce a result in the form of information or signals.

\section{Sound system}

A Sound system that is usually found in one part a computer device. Sound systems are combined into one with a laptop, besides that there is also a separate device. The various types of Technology have shaped the way teachers teaching English and of types of Technology that have been used to language laboratory is one of the types of Technology provide language learners. The use of ICT making language teaching more exciting, teachers believe can't be separated with the success of teaching and learning activities. Types of Technology either non web-based or web-based, they facilitate languange learning, teaching languange using 
Technology poses many challenges and teachers must able to solve some technical problems in the classroom.

The variety of so many and different media and technology that can be used to obtain information and knowledge can be classified into non-projected media like photographs, diagrams, exhibition materials and models. Media that can be projected, audio media such as cassettes, compact disc (CD) audio that contains recordings, sources and recordings of music. Media motion pictures or video media such as VCD, DVD, computer-based learning, multimedia and computer networks. All these varieties have their own characteristics in conveying information and knowledge to the learners, especially in the process of teaching and learning processes like audio medium is usually used for training and developing ability to hear and understand information through the element of sound especially in learning English for example audio medium can be used to practice pronunciation and a learner's ability to understand a verbally expressed story known as comprehension listening.

\section{f. English Learning Apps \\ 1. Quipper School}

Quipper is an online platform/application that we can all use for free for teaching and learning English as a foreign Language. Quipper also known as quipper school, is a web-based online learning application. Quipper provides the teachers and the students used web-based learning application to supports via virtual storage that allows them upload and keep their powertpoint presentasions, PDF files, pictures, and online video. This application also can be able to helps teachers for monitoring their students' learning without encountering of time. As a web based learning platform, in Quipper, teachers can develop learning materials that are of course being enriched by visual and audio media, like text with its illustration, pictures, videos or even other multimedia resources.

\section{Acapela Group}

Acapela group is an application that can makes it so easy for English teachers to help them to develop their students' ability in Listening skills. Teachers typing Acapella sentences will process these sentences into the sounds we want. Acapela helps the teachers to makes it easy for them to teach different listening and pronunciation between the british version of English and also the american version of English. By using Acapela, the teachers also can be able to choose the desired speaker accent and gender.

3. E-book

The students can be able to improve their skills by using E-book. Or while listening to music through students assigned to read books on the booktrack and they will read while 
listening to music in accordance with the storyline of the book and the teacher can also assign students to create stories in the booktrack and design their own music they like other than to read the skills of this platform can also be used in writing skills. Teach different listening and pronunciation between british English and american English and choose the desired speaker accent and gender.

Using E-book students can improve their skills and abilities in reading or while listening to music through students assigned to read books on the booktrack and they will read while listening to music in accordance with the storyline of the book and the teacher can also assign students to create stories in the booktrak and design their own music they like other than to read the skills of this platform can also be used in writing skills. this application can be downloaded in playstore or i-store.

\section{Google Clasroom}

Google Classroom is absolutely considered as one of the best platforms out there for improving teachers work flow because it does providing a set of so many useful and effective features that make it an ideal application to be used by the teachers. The benefit of using google lassroom is the teachers can be able to manage and create or even collect the assignment from the students that has been given by the teachers before. Also, the teachers can be able to spend more time for the student and less time on the paperwork.

There are several English learning applications like YouTube, Twitter, podcasting, Skype that can be used by the teachers and the students for their teaching \& learning activity.

a) YouTube

YouTube is an online platform/application of variey videos. We all can be able to access YouTube from our Personal Computer (PC), laptop or even also through mobile phone. The teachers are usually using YouTube to display the material in English learning. YouTube videos can be used in English languange teaching for various aspects of English to improve vocabulary, accents, pronunciation and many others, the teacher can be able to choose a part or show the students some of videos according to the the students' needs. In the classroom the teachers use YouTube to select a video or maybe some videos, and then they will eventually ask the student to narrate by making video like in YouTube to improve their skills of speaking ability.

b) Twitter

Twitter is a social networking application that could help as online education technology tool, the teachers can use a dozen activities for using an online education technology tool to engange students in classroom activities. Twitter can also be used for 
an English teaching likewise the teacher can ask the students to select a word the week and tweet it and requesting synonyms, antonyms of the word which is of course for improving the vocabulary insight of their students.

c) Podcasts

The students can also listening to new clips, music, video via the web and longer watching movie at the theatre or on tv or thrugh Personal Computer. A podcast is series of digital media files which are distributed by the internet. The teacher can download many free podcast for teaching English.

d) Skype

Using Skype provides unlimited possibilities for the teachers and also the students to collaborate each other anywhere in the world. The teachers may use skype to provide mentoring homework and the students can read, perform or present for the other students. It is an effective application for assissting learning process.

\section{Conclusion}

The writer found that technology is a term that refers to a body of knowledge. Technology includes the use of materials, tools, techniques and sources of power to make life easier. In education, Technology are really able to improve the teaching and leraning process. The variety of media and technology that can be used to obtain information and knowledge. Teaching with technology can more effective and fun cause the teacher has many ways to create the enjoyable class and it can make the students interesting in learning process.

Teachers can be able to use the different apps or trusted online resources to enhance the traditional ways of teaching and learning and to keep students more engaged in the classroom. The application that the teacher can be used like YouTube, Twitter, podcasting, Skype. Technology can help develop many practical skills, including creating presentations, learning to differentiate reliable from unreliable sources on the Internet, maintaining proper online etiquette, and writing emails. These are very important skills that can be developed in the classroom by using technology. So, using technology not only to get more information about something but also in the education it can make the students more effective, flexible, and interesting in learning process.

\section{REFRENCES}

Ahmadi, M. R. (2017). The impact of motivation on reading comprehension. International Journal of Research in English Education. http://www.ijreeonline.com. 
Becker, H. J. (2000). Findings from the teaching, learning, and computing survey: Is Larry Cuban right? Education Policy Analysis Archives, 8(51). Doi: http://dx.doi.org/10.14507/epaa.v8n51.2000.

Bull, S., \& Ma, Y. (2001) Raising learner awareness of language learning strategies in situations of limited recourses. Interactive Learning Environments, 9(2), 171-200. Doi: 10.1076/ilee.9.2.171.7439.

Clements, D. H., \& Sarama, J. (2003). Strip mining for gold; research and policy in educational technology-a response To fool's gold. Educational Technology Review, 11(1), 7-69. https://eric.ed.gov/?id=EJ673505.

Gençlter, B. (2015). How does technology affect language learning process at an early age? Procedia - Social and Behavioral Sciences, 199(2015), 311 - 316. Doi: 10.1016/j.sbspro.2015.07.552.

Harmer, J. (2007). The practice of English language teaching. England: Pearson. www.worldcat.org/title/practice-of-English-language-teaching/oclc/149005881

Pourhossein Gilakjani, A. (2013). Factors contributing to teachers' use of computer technology in the classroom. Universal Journal of Educational Research, 1(3), 262-267. Doi: 10.13189/ujer.2013.010317.

Chhabra, 2012. Use of E-learning tools in teaching, English.international journal of computing and business research. (online)chhabra.purva@gmail.com on acces desember 2019.

Mulyono, Herry 2012. Using Quipper As An Online Platform For Teaching and Learning As A Foreign Languange, (online), Vol. 23, No 2,(TEFLIN journal).Teaching English with Technology,16(1),59-70, Retrieved from http://www.tewtjournal.org.

Iftakhar, Shampa. (2016). Google Classrooms: What works and How journal of Education and social Science, Vol. 3, (Feb)

Zhanghongling (The development tendency of the modern foreign language teaching and the computer assisted instruction. Computer- Assisted Foreign Language Education 3 